\title{
The Importance of Being Informed: Experimental Evidence on Demand for Environmental Quality ${ }^{1}$
}

\author{
Jyotsna Jalan and E. Somanathan ${ }^{\text {b,c }}$
}

\begin{abstract}
To what extent does information affect the demand for environmental quality? A randomly selected group of households in an Indian city were informed whether or not their drinking water had tested positive for fecal contamination using a simple, inexpensive test kit. Households initially not purifying their water and told that their drinking water was possibly contaminated, were 11 percentage points more likely to begin some form of home purification in the next 8 weeks than households that received no information. They spent $\$ 7.24$ (at PPP) more on purification than control households. By way of comparison, an additional year of schooling of the most educated male in the household is associated with a 3 percentage-point rise in the probability of initial purification, while a standard-deviation increase in the wealth index is associated with a 12 percentage-point rise in this probability and an $\$ 11.75$ rise in expenditure. Initially purifying households that received a "no contamination" result did not react by reducing purification. These results suggest that estimates of the demand for environment quality that assume full information may signficantly under-estimate it.
\end{abstract}

Keywords: Environmental quality, drinking water, information, awareness, experiment, averting behavior.

JEL Codes: I12, O10, Q53, Q56

\footnotetext{
${ }^{1}$ Financial support from the South Asian Network for Development and Environmental Economics (SANDEE) is gratefully acknowledged. We thank the Office of Registrar-General, Census India, for providing enumeration-block level data and copies of census maps, Professor Shahid Jameel of the International Centre for Genetic Engineering and Biotechnology for incubator space, and Mr. S.N. Prasad at TARA for information about the water test kits. Tushi Baul, Saraswata Chaudhuri, Kamaal un Nabi Khan, Sreemoyee Moitra and Arindam Nandi provided excellent research assistance. Khan and Moitra and the survey team successfully implemented the surveys. Abhijit Banerjee, Shreekant Gupta, M.N. Murty, Arindam Nandi, Arijit Sen, Priya Shyamsundar, Rohini Somanathan and Jeff Vincent gave useful comments at various stages of the project. Finally, we thank Esther Duflo and two anonymous referees of the journal for making this a better paper.

${ }^{a}$ Centre for Studies in Social Sciences Calcutta (jjalan@cssscal.org)

b Planning Unit, Indian Statistical Institute, Delhi (som@isid.ac.in)

${ }^{c}$ Corresponding author: 7 SJS Sansanwal Marg, New Delhi 110016, India. Tel: 9111 51493939. Fax: 91 1151493981.
} 


\section{Introduction}

Environmental quality is generally thought to be a normal good, possibly a luxury good. However, observed positive correlations between income and environmental quality might overstate the importance of income because the poor are likely to be less informed about health risks than the rich. For example, 70 percent of those surveyed in a village in rural Bolivia thought that diarrhea was a normal occurrence in childhood (Quick et. al., 1997) while 45 percent of those surveyed in an Indian city in the study reported here did not include drinking contaminated water among the possible causes of diarrhea. The literature in economics, unlike that in public health, has laid much more emphasis on household wealth than on information as a determinant of willingness to pay to protect oneself from environmental and health hazards. ${ }^{2}$ The question is: Just how significant is the role of information in the demand for environmental quality?

To address this question we devised an experiment to provide households with exogenous information and measure its impact on averting behavior and expenditure, that is, on actions taken to reduce exposure to an environmental hazard. ${ }^{3}$ We chose household water quality as the environmental good because it is possible for households to take averting actions and incur expenditures even in the short run, and because it is one of the important environmental and health issues in developing countries. We provided a randomly selected treatment group of households with information about their water quality and available methods of improving it. The information was based on a test for the presence of bacteria of fecal origin. Eight weeks later, we recorded any changes in their in-home water purification behavior that had ocurred in the interim and compared these with the same data for a control group.

\footnotetext{
2 This is exemplified in the literature on the Environmental Kuznets Curve surveyed in Borghesi (1999) and Levinson (2002).

${ }^{3}$ Averting expenditure is a lower bound for willingness to pay (WTP) for better environmental quality. It may be strictly less than WTP because private averting expenditures may not be undertaken up to the point of eliminating a hazard. See, Abdalla et. al. (1992), Bresnahan et. al. (1997), and Harrington et. al. (1989) for details.
} 
The experiment was conducted in Gurgaon, a suburb of Delhi with wealth and education levels that are higher than the national average. Between November and December 2003, we surveyed approximately 1,000 randomly selected households and tested their drinking water for the presence of fecal bacteria. About 60 percent of the water (before any home purification) tested "dirty". 4 To put this figure in perspective, in the United States, if even a single sample of tap water tests positive for fecal coliforms, the local water authority is in violation of federal regulations issued under the Safe Drinking Water Act. ${ }^{5}$ Moreover, local authorities must inform individual households about any violation of the standards in their jurisdiction. In India, on the other hand, tap water is unregulated and the results of any water quality tests conducted by government authorities are generally not made public (McKenzie and Ray, 2004).

In the second round, we informed a randomly selected group of about half the sampled households of their water test results and told them about the cost and likely efficacy of home water purification methods in use in Gurgaon at the time. Returning about eight weeks later, we found that households who had not been purifiying their water and who were told that their water was "dirty", indicating the likelihood, but not certainty, of fecal contamination, were 11 percentage points more likely to have made changes in water purification, handling and/or storage behavior than households who had not been informed of the test result $(p=0.013)$. Their averting expenditures increased by \$7.24 (PPP) more than those of the control group. ${ }^{6}$ They were also nearly 13 percentage points more likely to have had discussions on issues concerning drinking water. The latter two results are significant at the $1 \%$ level. On the other hand, discovering that their water was "clean" (probably not contaminated) did not induce initially purifying households to reduce their purification expenditure.

\footnotetext{
${ }^{4}$ Throughout the paper, we use the term "clean" to indicate that the water tested negative for the presence of fecal bacteria and the term "dirty" to mean that the water tested positive for the presence of fecal bacteria.

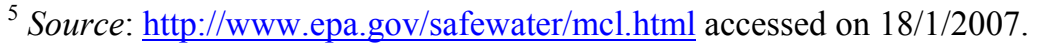

${ }^{6}$ We have used the World Bank's PPP conversion factor of 9 rupees per US $\$$ to convert the amount in Indian rupees to PPP-adjusted US \$. This is what we do throughout the paper.
} 
The mean averting expenditure prior to our intervention was $\$ 42$, and a simple calculation shows that if all households were given the information that our treatment group got, averting expenditure (a lower bound for WTP for safe water) would be predicted to rise by $6.5 \%$. This effect on purification expenditure is of the same order of magnitude as that of a one-standard deviation increase in the wealth index, estimated from the cross-section. These results show that even a single instance of targeted information to households, despite the qualifier about the accuracy of the test, can have an effect on awareness and disease averting expenditures. More generally, our results suggest that measuring the demand for environmental quality and attempting to draw welfare and policy conclusions from it without addressing the issue of under-provision of information can lead to significant underestimates of demand.

As yet, little attention has been paid to this issue in the literature. The only other experimental study from a developing-country that we are aware of is that by Madajewicz et. al. (2005) who studied the impact of informing Bangladeshi households about the arsenic levels in their well water. They find that 60 percent of households with unsafe wells changed their water source while only 14 percent of those with safe wells did so. The proportion of those responding to information is much larger than in our study, possibly because their cost of switching was very low, subjects were unambiguously warned that their wells were unsafe, and generally knew that arsenic poisoning is deadly. Moreover, information dissemination was continuous and intensewells were marked with skulls and crossbones signs if they did not meet the government's prescribed standards on arsenic levels. Finally, households had a much longer response time.

In another study, different types of information booklets on cancer risks from radon gas were given to a sample of US households in the state of New York by the Environmental Protection Agency (Smith et. al. (1995)). The researchers found that households were persuaded to take mitigating action on receiving information on the radon levels and on being convinced about the health risks of radon exposure. 
The motivation and a simple model underlying the experiment are laid out in Section 2. The experiment and the sampling design are described in Section 3. Section 4 provides details about the data and reports some summary statistics. Section 5 presents the main results of the experiment and Section 6 concludes.

\section{Motivation and a simple model underlying the experiment}

In 1998-99, the National Family Health Survey of India (NFHS) found that $16 \%$ percent of urban households with children in the 0-3 age group had a case of child diarrhea in the two weeks preceding the survey. Despite this high incidence of disease we found (Jalan et. al., 2003) that nearly half of all households in the urban sample of the NFHS did not purify their water. Of those who did, only about 20 percent used methods (i.e. boiling and electronic filters) that are thought to reliably remove pathogens. In that paper we found that a change from the bottom to the top quartile of the wealth distribution was associated with a 160 percent increase in purification expenditure, while a move from the bottom to the top quartile of the distribution of female schooling was associated with a 120 percent increase. Other indicators of awareness such as exposure to news media and certain kinds of occupations were also associated with significant increases in purification expenditure. The regressions on which these results are based had an extensive set of controls, but as is usual with survey data, it is impossible to rule out non-causal interpretations of these findings.

In this paper we provide households with exogenous information about their water quality and then observe changes in their averting behavior in order to unambiguously identify the impact of information.

Willingness to pay for safe water is the sum of averting expenditure and the remaining expected utility loss from unsafe water (since the expenditures will not, in general, provide full protection from the hazard). As discussed below, we found that averting expenditure probably provides only partial protection from unsafe water. We nevertheless focused on averting expenditure because of its ease of measurement. 
A simple model of the household's decision-making process in our experiment is outlined below. We note that households not initially purifying their water cannot reduce their averting expenditures and those initially purifying water have only a limited scope to do so.

In the initial time period, a household will not purify its water if:

$$
D\left(p^{0}\right)-c(w)+v<0 .
$$

$D$ denotes the utility differential between purification and no purification, $p^{0}$ denotes a household's prior probability that its water is unsafe or prone to contamination, $w$ denotes the household's wealth, $c(w)$ the utility cost of purification and $v$ is an error term. Subsequently, the household will start purifying its drinking water if

$$
D(p)-c(w)+u>0
$$

where the distribution of $u$ is conditional on (1) and the posterior probability $p$ of the water being unsafe equals $p^{0}, p^{\mathrm{d}}$, or $p^{\mathrm{c}}$ respectively depending on whether the household is in the control group, gets a "dirty" test result, or a "clean" test result.

Let $\lambda=\operatorname{Pr}$ ("Dirty" | unsafe) be the probability of a "dirty" water result conditional on the water being unsafe and $\mu=\operatorname{Pr}$ ("Clean" $\mid$ safe) be the probability of a "clean" water result conditional on the water being safe. The posterior probability of unsafe water conditional on a "dirty" water test result is:

$p^{d}=\operatorname{Pr}($ unsafe $\mid$ "Dirty") $)=\frac{\lambda p^{0}}{\lambda p^{0}+(1-\mu)\left(1-p^{0}\right)}$

If the test is informative, which we assume, then $\lambda>1-\mu$. We also assume that the household is not certain about the safety of its water so that $1>p^{0}>0$. It follows immediately that $p^{\mathrm{d}}>p^{0}$, and so by (1) and (2), a "dirty" result makes it more likely that a non-purifying household will switch to purification. (It is easily seen that a "clean" result would not induce the household to increase its averting expenditure by starting to purify its water because $p^{\mathrm{c}}<p^{0}$.)

A household that was purifying before our intervention would have the inequality (1) reversed and will stop purifying if (2) is reversed. The posterior probability that unpurified source water is unsafe conditional on a "clean" test result is 


$$
p^{\mathrm{c}}=\operatorname{Pr}\left(\text { unsafe } \mid \text { "Clean") }=\frac{(1-\lambda) p^{0}}{(1-\lambda) p^{0}+\mu\left(1-p^{0}\right)}\right.
$$

which is less than $p^{0}$. Thus a "clean" test result on an initially purifying household's source water makes it more likely that it will stop purifying. Information thus has opposing effects on averting expenditures depending on whether the news is good or bad.

However, the effect of getting a "dirty" result may be stronger than that of getting a "clean" result. To see this, consider the case when the water source may be prone to contamination, perhaps due to a cracked pipe, and if (and only if) it is, then a fraction $f$ of samples contain fecal matter. Now $p^{0}$ can be interpreted as the prior probability that the pipe is cracked so that the water is unsafe. Suppose the test is highly accurate so that $\lambda=$ $\operatorname{Pr}($ "Dirty" $\mid$ unsafe $) \approx f$ and $\mu=\operatorname{Pr}$ ("Clean" $\mid$ safe $) \approx 1$, then for any $1>p^{0}>0$, it follows that $p^{\mathrm{d}} \approx 1$, while $p^{\mathrm{c}} \approx \frac{(1-f) p^{0}}{(1-f) p^{0}+\left(1-p^{0}\right)}$, which, for small $f$, is close to $p^{0}$. In this case, a "dirty" result leads to a discrete jump in the probability that the water is unsafe, while a "clean" result leads to just a small decline in this probability.

There are two more implications of the model that are worth mentioning. First, it is clear from (1) and (2) that the effect of a "dirty" result on the averting expenditure of initial non-purifiers will be greater for those with higher wealth. Second, since $p^{\mathrm{d}}$ is increasing in $p^{0}$, if greater awareness of health hazards from contaminated drinking water raises $p^{0}$, then those with higher initial awareness will be more likely to switch to purification in response to a "dirty" result." We measured awareness in the course of the survey as described below.

\section{The Experiment}

\footnotetext{
${ }^{7}$ Awareness of the germ theory of disease and of the notion of infection will cause individuals to assign a positive probability to their water supply being contaminated in an environment with high disease levels. An individual who is unaware of such concepts will have a prior that is effectively zero, not a uniform prior.
} 
Our study area was the city of Gurgaon, a suburb of the national capital, New Delhi. ${ }^{8}$ We chose Gurgaon because we wanted a residential urban area where the water supply to households was not of uniform quality, where there was some heterogeneity among the population in terms of their general awareness of sanitation and health issues, and that was sufficiently compact so as to make for easy implementation of the survey.

In July and August 2003, we conducted a pilot survey of the quality of water supplied to residential households in randomly chosen areas of Gurgaon. We used watertesting kits that test for the presence or absence of bacteria of fecal origin. While most fecal bacteria are not themselves pathogenic, their presence shows that pathogens may be present since most water-borne pathogens are of fecal origin. Direct tests for the presence of pathogens are expensive and so testing for fecal bacteria is the standard method of testing for exposure to waterborne disease worldwide (WHO, 1997). Our test kits were purchased from TARA, a non-profit development organization based in Delhi. More than 90 percent of the approximately 30 samples from the pilot survey were contaminated. $^{9}$

We used 2001 census data to create an enumeration block (EB) level wealth index based on the first principal component of a number of indicators. ${ }^{10}$ We excluded EB's with fewer than 50 census buildings at the time of the 2001 census house-listing. Our final sample frame included 195 EB's in the municipality, and 6 and 7 EB's in Sukhrali

\footnotetext{
${ }^{8}$ There are two sections in Gurgaon - new Gurgaon, an area that has witnessed rapid growth over the last decade and old Gurgaon which has been in existence for four to five decades. Our sampling frame includes only old Gurgaon for which the 2001 census maps were readily available.

${ }^{9}$ Although the hydrogen sulfide test we used is known to produce false positives, disagreement rates with other tests are low: $\mathrm{H}_{2} \mathrm{~S}$ tests have been shown to agree with other tests at rates ranging from 71 to 100 percent in different studies, with only one study showing a disagreement rate greater than 20 percent (Sobsey and Pfaender, 2002). Furthermore, it is usually the case that even when a false positive is found, it is due to organic matter, itself an indicator that the water supply system has been breached.

${ }^{10}$ This was created in the same way as the household-level index described in Section 4 below. The variables included in the wealth index are: Predominant material of the floor, wall, and roof, condition of house, ownership status, number of dwelling rooms within the house, drinking water source, lighting source, whether kitchen, bathroom, latrine are within the house, type of waste-water outlet house is connected to, type of fuel used for cooking, whether household possesses a radio/transistor, television, telephone, bicycles, scooter/motor cycle/moped, car/ jeep/ van, and whether the household avails of banking services.
} 
and Gurgaon villages respectively. ${ }^{11}$ Each EB was categorized into a wealth quintile using our constructed wealth index. Approximately 3-4 households were sampled from each EB in a way so that we over-sampled households from the middle three quintiles and under-sampled from the top and bottom quintiles. ${ }^{12}$ Our final sample consisted of 60 and 70 households respectively from Sukhrali and Gurgaon villages representing the lowest wealth quintile, and 870 households (120 from the top quintile and 250 each from the middle quintiles) from Gurgaon municipality. ${ }^{13}$

Between November $13^{\text {th }}$ and December $23^{\text {rd }} 2003$, we conducted the first round of the survey and gathered information on household demographics, source of drinking water, whether they used any purification method at the time of survey, and general awareness about health and sanitation issues. The awareness module was administered first with households being told that the survey was about health and awareness so that their responses would not be influenced by questions on water. ${ }^{14}$ A time-line of the survey is given in Figure 1.

\section{[Insert Figure 1 here]}

At the end of each interview, samples of the households' unpurified and purified (if any) water were collected in testing bottles and resealed immediately after collection. The bottles were kept for 48 hours at body temperature in an incubator before results were recorded. $^{15}$

\footnotetext{
${ }^{11}$ The latter two were once villages but are now in the middle of urban Gurgaon.

${ }^{12}$ We adopted this sampling strategy to ensure heterogeneity in responses to the experiment given that the poor may be constrained by wealth from acting upon the information they would receive during the experiment and most of the wealthy might already be using some home water purification method.

${ }^{13}$ Two possible substitutes were included for each household in the sample. 296 households were actually substituted, 50 because no respondent was available, 76 because they did not wish to be surveyed, and 171 because the house could not be located from the map or was a commercial establishment.

${ }^{14}$ A copy of the household survey questionnaire is available from the authors.

${ }^{15}$ The use of the incubator was convenient because we had a large number of samples, but is not required.
} 
During the second round (January $17^{\text {th }}-$ February $1^{\text {st }}, 2004$ ), we administered the treatment to approximately half of the originally selected sample. However, our concern was that randomizing treatment among households could potentially contaminate the control group because of possible proximity of treatment and control households. So we randomized at the EB level and chose 107 EBs as treatment units covering 497 treatment households. $^{16}$ All sampled households in the treatment EBs were given the treatment. The number of treatment EBs was chosen so that the number of households in the treatment group was close to half the full sample. Appendix Table 1 shows that there were no systematic differences in relevant observable variables across the two groups.

Households in the treatment group were given their test results and a handout (see Appendix 1) explaining the results. Each household was also given its water sample bottle(s) and told that if the contents of a bottle were black, then its water was likely to contain germs but this simple test could not confirm that the water was contaminated. The remainder of the handout suggested that the households could, if they wished, adopt one of a number of purification methods in use in Gurgaon as appropriate for their budget. ${ }^{17}$ The respondent's attention was drawn to the different locally available methods, brief details about the effectiveness of each in removing pathogens and their cost. Information on safe water storage and handling practices were also included in the handout.

In the third and final round (March $1^{\text {st }}-28^{\text {th }}, 2004$ ), we revisited all sampled households. Households in the control group were visited first, and were given their test results and the handouts that the households in the treatment group had received earlier in the second round. This meant that households in the treatment group were surveyed approximately eight weeks after they were given the information about their water quality and the handout. We surveyed the households (see Appendix 2 for this questionnaire) to

\footnotetext{
16 Even though initially we had surveyed 1,006 households in our first visit, we had to drop some households due to sample attrition.

${ }^{17}$ Filter prices were obtained from a market survey conducted in Gurgaon between the first and second rounds.
} 
see whether they had changed their water purification behavior in any way between the first and third rounds of the survey.

There was some attrition from our original sample due to relocation of households to another address. Our final complete sample (i.e. three rounds of data for the treatment group and two rounds for the control group) consisted of 965 households (497 treatment and 468 control households) indicating a sample attrition of 4 percent. There were no statistically significant differences between the observed characteristics of the households that dropped out and those that remained in the sample. Nor was there a statistically significant difference in the proportion of drop-outs from the treatment and control groups. (See Appendix Table 2 for details).

\section{Data and Descriptive Statistics}

Tables 1 and 2 report several descriptive statistics on information gathered during the first round of the survey.

\section{[Insert Table 1 here]}

In Table 1 we report statistics on the quality (as measured by our water test results) of water supply and purification behavior by households in Gurgaon. Contamination of unpurified water is high - 61 percent of unpurified water tested "dirty" i.e., positive for the presence of fecal bacteria. Only 42 percent of surveyed households use private purification methods (including boiling) and of those, 28 percent use methods like straining or non-electric filter, that do not ensure full protection against fecal contamination. 56 percent of home-purified drinking water tested "dirty". ${ }^{18}$ The average

\footnotetext{
${ }^{18} 53$ households who said that they were purifying their water but failed to give us a sample of their purified water during the first round of the survey were assumed to be not purifying their drinking water. All regressions were run making the opposite assumption as well. The results are very close to our favored specification and so are not reported separately.
} 
annual household expenditure on purification in the sample was $\$ 42 .{ }^{19}$ It was $\$ 100$ among households that used some form of purification. ${ }^{20}$ Using the latest available household consumption expenditure numbers for urban Haryana (NSS Report No. 484, December 2003), these purification expenditure numbers suggest that an average household in Gurgaon was spending less than .05 percent of its total annual expenditure on water purification methods. ${ }^{21}$

A fecal contamination rate of 61 percent is high relative to developed countries with zero fecal contamination of tap water, but is comparable to some parts of India based on fragmentary evidence that is available. For example, the Sukthankar Committee report submitted to the Government of Maharashtra, finds bacteriological contamination in 10 percent of water samples collected from municipalities state-wide in 1999, and 14 percent for Mumbai metropolis alone. In another survey in Kolkata in 2003, 63 percent of taps had high levels of fecal contamination (McKenzie and Ray, 2004). Possible reasons for such high contamination levels include inadequate sanitation, sometimes large numbers of animals in urban areas, and leaky public water supply and sewage systems. In Gurgaon, as in most of urban India, water is supplied intermittently for a few hours a day. As a result, pipes are not always pressurized and (illegal) private pumps attached to the main lines may suck in contaminated water.

Of the 186 households whose water tested "clean" before purification, in 72 (42 percent) cases the water tested "dirty" after purification. These numbers suggest that considerable contamination is taking place within the household. This is probably because the intermittent supply leads households to store water. Within-household fecal contamination of drinking water is a commonly observed phenomenon in developing countries (Wright et. al., 2004). However, at least one study has shown that within-

\footnotetext{
${ }^{19}$ PPP exchange rates were used to convert Indian rupees into international dollars. PPP $\$=$ Rs.9, Nominal exchange rate $\$=$ Rs. 45

${ }^{20}$ Expenditures were calculated by annualizing fixed costs where necessary.

${ }^{21}$ The average per capita consumer expenditure in Haryana was $\$ 1500$ and the average household size was 4.8 members.
} 
household fecal contamination of stored water is less infectious than pathogens introduced from outside the household (VanDerslice and Briscoe, 1993).

Given pervasive externalities from disease prevention and the likelihood of recontamination of stored water within households, a continuous pressurized publicly treated water supply may be more effective in reducing diseases compared to private home treatment methods. We however, focused our study on home treatment because it is the only easily measurable response we can expect from households in the short term. It is still useful to estimate the extent to which the demand for safe water changes with the inexpensive information we provide so that public provision of safe water may be better financed.

About 7 percent of households had at least one case of diarrhea in the month preceding the survey. However these percentages almost surely understate the annual incidence of diarrhea because there are significant seasonal variations with most cases occurring during the summer months between May and August. Dasgupta (2004) using hospital records for the years 1996-1998 from poor localities in neighboring Delhi, reports that only 1 percent of the annual numbers of recorded diarrhea cases were observed in the months of November and December while the months of June, July, and August accounted for 69 percent of total cases. ${ }^{22}$ We did not find the difference in diarrhea incidence between households with and without contaminated drinking water to be statistically significant.

\section{[Insert Table 1 here]}

Gurgaon households are better educated and wealthier than the average urban Indian household. According to the 2001 census, literacy rates for males and females (in the $7^{+}$age group) in urban India were 80 percent and 73 percent respectively. Assuming that all those who have completed one year of schooling are literate, the corresponding percentages for our sample are 93 and 86 respectively. Likewise, the percent of

${ }^{22}$ Owing to circumstances beyond our control we could not conduct the survey during the summer months when diarrhea would be more common and differences in its incidence more likely to be detectable. 
households possessing consumer durables like a television, telephone, two-wheeler or four-wheeler are higher than the average for urban India. In urban India, 64 percent of households have a television while in Gurgaon 95 percent do. The analogous numbers for telephones, two-wheelers, and four-wheelers are 23 and 80, 25 and 76, and 6 and 38 for urban India and Gurgaon respectively (Source: Census 2001 and Gurgaon sample survey).

Despite these above average education and wealth statistics, when asked what causes diarrhea, only 54 percent of the households mentioned drinking contaminated or "dirty" water, and strikingly, only 8 percent mentioned infection (Table 2), indicating a low level of awareness about the health hazards associated with poor drinking water quality.

\section{[Insert Table 2 here]}

We created wealth and awareness indices using the first principal component of appropriate variables. That is, the weights used on each of the variables were such that the linear combination captured the greatest amount of information common to all variables. The wealth and awareness indices for the $i^{\text {th }}$ household were thus defined as:

$$
\begin{gathered}
w_{i}=\sum_{j} f_{j} a_{i j} \quad \forall i=1, . ., N \\
\text { aware }_{i}=\sum_{j} g_{j} b_{i j} \quad \forall i=1, . ., N
\end{gathered}
$$

where $a_{i j}, b_{i j}$ are the standardized (mean zero and standard deviation one) variables $j$ for household $i$, and $f_{j}, \mathrm{~g}_{j}$ are the "scoring factors" for the $j^{\text {th }}$ asset. $\left(f_{l}, \ldots, f_{n}\right)$ and $\left(g_{l}, \ldots, g_{n}\right)$ maximize the sample variance of $w$ subject to the constraints $\sum_{j} f_{j}^{2}=1$ and $\sum_{j} g_{j}^{2}=1$ respectively. A higher value of the index indicates more wealth or a more aware household. We created dummy variables for households having values of these indices higher than the median.

The variables included in the wealth index were: possession of a refrigerator, radio, computer, television, phone, washing-machine, bicycle, two-wheeler, four- 
wheeler, whether household owns the house it lives in, whether household possess land other than current residence, whether the house has a permanent structure, whether there is a separate kitchen and whether there is an air-exhaust outlet in the kitchen.

The (binary) variables included in the awareness index were: respondent listed contaminated water among the causes of diarrhea, mentioned infection among the causes of diarrhea, respondent stated diarrhea can be prevented by purifying water, respondent thinks the government can prevent diarrhea by providing clean water, respondent thinks government can prevent diarrhea by providing proper sanitation, and household uses a safe method to draw their drinking water from a storage container.

In Appendix Table 3, we report marginal effects from probit regressions of whether or not a household adopts any drinking water purification method on a number of explanatory variables for the full sample and for each of two wealth categories, above and below median wealth. Awareness does not significantly raise the probability of purification for those in the full sample or lower wealth class. The schooling of the most educated adult male is significant in household purification adoption. The effects of wealth and education are significantly higher among households above median wealth. ${ }^{23}$

\section{Results}

We estimate the following reduced form of equation (2) from Section 2:

$$
\begin{gathered}
y \quad=1 \quad \text { if } D(p)-c(w)+u=x^{\prime} \beta+u>0, \\
=0 \quad \text { otherwise, } \\
x^{\prime} \beta=\alpha+\beta_{1} \text { (Treatment x "Dirty") }+\beta_{2} \text { (Treatment x "Clean") }+\beta_{3} \text { (“Dirty") }
\end{gathered}
$$

In this equation, $y$ is a measure of a behavior adopted by households between the third and first rounds, "Dirty" is a dummy for a positive test result indicating the presence of fecal bacteria in the household's water source, "Clean" denotes a negative test result, and "Treatment" is a dummy for a treatment, as opposed to control, household. The coefficient $\beta_{1}$ is the treatment effect on households with "dirty" results, and $\beta_{2}$ is the treatment effect on households with "clean" results. The inclusion of the "Dirty" dummy

\footnotetext{
${ }^{23}$ Due to possible endogeneity, these results should be seen as descriptive.
} 
controls for possible non-randomness in those with "dirty" results. The model in Section 2 predicts that purification expenditure would rise $\left(\beta_{1}>0\right)$ for initially non-purifying households getting a "dirty" result, and that it would fall $\left(\beta_{2}<0\right)$ for initially purifying households getting a "clean" result on their source of water. It also suggests that the former effect may be larger than the latter with the result that information would raise the overall willingness to pay for cleaner water.

Note that, because all right-hand side variables in (3) are dummies, we are not imposing linearity, and the coefficients are simply differences in conditional means of $y$.

We use three measures of household behavior. In the first and broadest, $y$ is a dummy for any change in water purification or storage, i.e. started using a water purification method if not previously doing so, stopped purifying its water if initially doing so, changed its purification method from a previous method, changed candle-filter in electronic or non-electronic water filters, and/or bought an annual maintenance contract for existing filtration equipment, changed its water storage, or method of drawing water from a storage container. The second measure is the increase in expenditure on home water quality, negative if expenditure falls. This includes expenditures incurred on buying a new purification system, changing the existing system, on maintenance or repairs of existing purification systems, as well as stopping expenditures on existing purification systems. The third measure is a dummy variable called "discuss" that takes the value one if any or all of the household members had discussions with friends, relatives or others about drinking water quality and water purification issues between the first and third rounds of the survey.

We estimated equation (3) separately for households not initially purifying their water and for those initially purifying their water as their responses are predicted to be different by the model in Section 2 above. As a descriptive measure, we also report the results on the full sample in Table 3. We want to know how willingness to pay for safe water as revealed by averting behavior will respond to information about drinking water quality.

\section{[Insert Table 3 here]}


Table 3 reports the results from our experiment. All standard errors have been corrected for clustering at the EB level and the estimates have been weighted by the inverse probability of sampling.

As predicted by the model, for those not purifying their water, the effect of learning that their water is "dirty", is positive and significant, by all three measures (in bold, in the first row of Table 3). ${ }^{24}$ Non-purifying households that learn that their water is "dirty" are 11 percentage points more likely to change their averting behavior than households who do not learn this $(p=0.013)$. This effect is comparable in size to the marginal effect of wealth on initial purification in a probit regression (Appendix Table 3), which is 11 percentage points for a one-standard deviation change in the wealth index.

Purification expenditure rises by 65 rupees ( $\$ 7.24$ at PPP) more than that of households with "dirty" water who remain un-informed (significant at 1\%). Again, the effect is comparable in size to the marginal effect of wealth in the cross-section which is 106 rupees (\$11.75 at PPP) for a one-standard deviation change. Mean initial purification expenditure in the full sample was $\$ 42$ at PPP. Information significantly raises the averting expenditure of those who receive bad news.

We now turn to initially purifying households who receive good news, that is, get a "clean" test result on their source water. The model suggests that this would make them less likely to continue purification although this effect may be considerably weaker than the effect of bad news. The relevant results are in bold in the second row of Table 3 . We see that these households' purification behavior and expenditure is not statistically significantly different from those who are not informed about their "clean" test results. The sign of the effect on expenditure is, in fact, positive. Thus the effect of information on the averting expenditure of those who receive good news does not counter-balance the rise in averting expenditure of those who get bad news. This is consistent with the model. The net effect of information on averting expenditure is positive.

\footnotetext{
${ }^{24}$ It may be recalled that all treatment households got our handout (Appendix 1), so the treatment is the joint impact of the test result and our handout. As can be seen from Table 3, however, "dirty" and "clean" results have very different impacts on purification and expenditures of initial non-purifiers.
} 
To calculate the total predicted rise in averting expenditure, we note that the size of the information effect has to be multiplied by the proportion of initial non-purifiers with dirty results, since this sub-group is the only one with an estimated response that is significantly different from zero. We find that the predicted rise in averting expenditure consequent on the information we provide is $6.5 \%$. Recall, however, that the willingness to pay for safe water includes the compensating variation from the residual risk. The change in averting expenditure is, therefore, likely to under-estimate the impact of information on willingness to pay for both purifiers and non-purifiers. It may also be the case, of course, that regular, official water testing will have a greater impact than our oneshot intervention.

We comment on some other interesting facts that emerge from Table 3. First we note that those treatment households who get a "dirty" result are 13 percentage points more likely to discuss water quality issues with someone than corresponding control households. This is true for both non-purifiers and purifiers. Second, a look at the bottom row of Table 3 shows that in the two-month period between the first and third rounds, a sizeable fraction of control households changed their purification behavior, and this applied to both initial non-purifiers and initial purifiers. The size of this fraction and the short time period suggests that the first-round survey drew households' attention to water-quality issues and prompted behavioral change. Note that expenditures rose more for initial purifiers than for non-purifiers. Examination of the break-up of expenditures suggests that this was partly due to households with filters undertaking maintenance expenditures.

We turn next to the implications of the model concerning wealth and awareness. These were that the more wealthy and more aware among the non-purifiers are more likely to respond to bad news by starting purification and undertaking averting expenditures. Since households" do not respond significantly to "clean" results, we use only the sample of non-purifiers with "dirty" water. We replace $x^{\prime} \beta$ in equation (3) by $x^{\prime} \beta=\alpha+\beta_{1}$ (Treatment $)+\beta_{2} * x_{u}+\beta_{3}($ Treatment $) * x_{u}$ 
where $x_{u}=w_{u}$ is a dummy for households having wealth greater than the median in one model, and $x_{u}=a_{u}$ is a dummy for households with awareness greater than the median in an alternative model. These results are reported in Table 4.

\section{[Insert Table 4]}

The difference $\beta_{3}$ in the treatment effect on purification and expenditure between upper and lower wealth categories is considerable. Households in the upper wealth category are more than 23 percentage points more likely to start purification. The richer households spend 104 rupees ( $\$ 11.57$ at PPP) more on purification in response to information than those with wealth below the median. Both these results are significant at the $5 \%$ level. The interaction of the wealth and information effects on expenditure can also be seen in Figure 2. As might be expected, while the treatment effect on discussions of water quality is positive (and significant at 10\%) its interaction with wealth is not significant.

\section{[Insert Figure 2 here]}

While the wealth interaction with the treatment effect is in line with the model's prediction, we do not find the same for awareness. Being a more aware person as proxied by the awareness index does not lead to additional changes in averting behavior patterns of households beyond the changes due to information that they receive about their water quality. This result parallels the finding from the cross-sectional probit regressions based on the first-round survey that awareness is associated with a higher probability of purification only for those above median wealth (Appendix Table 3).

We also estimated an alternative model (not shown in Table 4) where instead of using the awareness index categories as defined above, we used the maximum years of education among adult females as an awareness indicator. The results are similar with this measure of awareness also not making a significant impact on the treatment effect. 


\section{Conclusion}

In this paper, we asked to what extent targeted information affects the demand for environmental quality. We focused on the easily measurable component of willinness to pay for safe drinking water given by averting expenditure. We found that Gurgaon households who were told that their drinking water was "dirty" and was, therefore, likely to contain germs, were nearly 11 percentage points $(p$-value $=0.013)$ more likely to begin some form of home purification in the next 7 weeks than households with "dirty" water that received no information. They also spent 65 rupees (US \$7.25) more on purification. This effect can be compared to that of the 104 rupee increase in expenditure resulting from a one-standard deviation increase in the wealth index, estimated from the crosssection. Households that received a negative test result (i.e., "clean" water) did not behave significantly differently with regard to purification from households that received no information. This one-shot information is predicted to raise averting expenditure by $6.5 \%$ in the whole population.

Among the households that received a positive (i.e. "dirty") result, households above the median value of wealth were 23 percentage points more likely to start purifying their water than less wealthy households.

Public education campaigns that include sufficiently specific information about exposure to environmental risks can evidently make a significant impact on people's behavior. The water test kit that we used in our experiment costs approximately 20 rupees (\$2 PPP) per sample, is available from an NGO in Delhi, and is simple enough for households to use themselves. It is notable that it has an effect on the probability of purification equivalent to about two and a half times that of an additional year of schooling for the most educated member of the household and more than two-thirds that of a move from one wealth quartile to the next.

Our study shows that although Gurgaon is a relatively wealthy urban area in India, the publicly supplied water quality is very poor with over half the samples testing positive for fecal contamination. Gurgaon, like virtually all other Indian cities and many in the developing world, has an intermittent, not a continuous, supply of piped water. 
This implies that water is more likely to get contaminated outside the home, (since the pipes are not always pressurized), and also more likely to get contaminated within the home because it has to be stored before drinking. While the inconvenience of an intermittent water supply is all too obvious, its adverse consequences for health are not widely known. Indeed, as discussed in Section 3 above, the level of awareness in Gurgaon about the role of water in the spread of diarrheal disease is surprisingly low, given its economic condition.

In Jalan et. al. (2003), based on a representative survey of urban India, we could not definitively interpret the positive association that we found between schooling (and other variables that capture awareness of the hazards of contaminated water) with purification behavior as being causal. The magnitudes of the estimated awareness effects were comparable to those of the wealth effects. A causal interpretation of those results is supported by the experiment reported in this paper.

The experimental results suggest that to the extent that the failure of public authorities to provide safe water is due to lack of demand (whether by way of political expression or lack of willingness to pay for improvements), regular water testing and public information campaigns can help mitigate this problem at a relatively low cost. More generally, they indicate that the possible under-provision of information should be taken into account whenever estimates of the demand for environmental quality are used for welfare or policy analysis. 


\section{References}

Abdalla, C.W., Brian A. Roach, and Donald J. Epp, "Valuing Environmental Quality Changes Using Averting Expenditures: An Application to Groundwater Contamination," Land Economics, 68(1992): 163-69.

Antle, John M., and Prabhu L. Pingali, "Pesticides, Productivity, and Farmer Health: A Philippine Case Study," American Journal of Agricultural Economics, 76 (1994), 418-430.

Borghesi, Simone, "The Environmental Kuznets Curve: A Survey of the Literature," FEEM Working Paper No. 85-99, 1999.

Bresnahan B., M. Dickie, and S. Gerking, "Averting Behavior and Urban Air Pollution," Land Economics, 73(1997), 340-357.

Dasgupta, Purnamita, "Valuing Health Damages from Water Pollution in Urban Delhi, India: A Health Production Function Approach," Environment and Development Economics, 9 (2004), 83-106.

Government of India, "Household Consumer Expenditures and Employment Unemployment Situation in India," NSS Report No 484, 2003.

Harrington, Winston, Alan J. Krupnick, and Walter O. Spofford, “The Economic Losses of a Waterborne Disease Outbreak," Journal of Urban Economics, 25(1989): 11637.

Jalan, J., E. Somanathan and S. Chaudhuri, "Awareness and the Demand for Environmental Quality: Drinking Water in Urban India," SANDEE Working Paper No. 4-03, 2003.

Levinson, A. "The ups and downs of the environmental Kuznets curve." In: J.A. List and A. de Zeeuw, Editors, Recent Advances in Environmental Economics, Edward Elgar, Cheltenham, UK (2002).

Madajewicz, M., P. Pfaff, A. van Geen, J. Graziano, I. Hussein, H. Momotaj, R. Sylvi, and H. Ahsan, "Can Information Alone Change Behavior? Arsenic contamination of groundwater in Bangladesh" mimeo, Columbia University, 2005.

McKenzie, D and Isha Ray, "Household Water Delivery Options in Urban and Rural India," mimeo Stanford University, 2004. 
Quick R., E. Mintz, J. Sobel, P. Mead, F. Reiff, and R. Tauxe, "A new strategy for waterborne disease prevention," $23^{\text {rd }}$ WEDC Conference Durban, South Africa: 340-2, 1997.

Smith, V. Kerry, William H. Desvouges, and John W. Payne, "Do Risk Information Programs Promote Mitigating Behavior?" Journal of Risk and Uncertainty, 10 (1995), 203-221.

Sobsey, Mark D., and Frederic K. Pfaender, "Evaluation of the $\mathrm{H}_{2} \mathrm{~S}$ Method for Fecal Contamination of Drinking Water," (Geneva: World Health Organization, 2002).

VanDerslice, James, and John Briscoe, "All coliforms are not created equal: A comparison of the effects of water source and in-house contamination on infantile diarrheal disease," Water Resources Research, 29 (1993), 1983-1995.

World Health Organization, Guidelines for Drinking Water Quality, (Geneva: WHO, 1997).

Wright, J., S. Gundry, and R. Conroy, "Household drinking water in developing countries: a systematic review of microbiological contamination between source and point-of-use. Tropical Medicine and International Health, 9 (2004), 106-117. 
Table 1: Quality of water and purification behavior of households in Gurgaon

\section{Quality of water}

Percent of 965 households whose unpurified water tested dirty for 60.95

fecal bacteria

Percent of 965 households whose drinking water (purified or not)

tested dirty for fecal bacteria

Percent of 965 households that used a purification system for

drinking water

Mean annual purification expenditure of all 965 households (standard deviation in parentheses)

379 rupees

Percent of the $\mathbf{3 9 6}$ households that used a purification system for

drinking water and the water tested dirty

Percent of the $\mathbf{5 6 9}$ households that do not use a purification system

for drinking water and the water tests dirty

\section{Purification behavior of households who purify their drinking water} ( $\mathbf{N = 3 9 6 )}$

Percent of households who use straining as their purification 5.01 method

Percent of households who use alum tablets as their purification method

Percent of households who use non-electric filter as their purification method

Percent of households who use electric filter as their purification method

Percent of households who use boiling as their purification method

Percent of households who use bottled water as their purification .78 method

- Standard errors in parentheses

- Estimates are weighted by inverse of sampling probability 
Table 2: Demographics, health outcomes \& awareness of households in Gurgaon

\begin{tabular}{|c|c|}
\hline \multicolumn{2}{|l|}{ Wealth characteristics } \\
\hline Percent of households owning a telephone & $\begin{array}{c}79.62 \\
(1.30)\end{array}$ \\
\hline Percent of households owning a computer & $\begin{array}{l}25.72 \\
(1.41)\end{array}$ \\
\hline Percent of households owning a two-wheeler & $\begin{array}{l}75.25 \\
(1.39)\end{array}$ \\
\hline Percent of households who say that the outside surroundings of their house is dirty & $\begin{array}{c}18.74 \\
(1.26)\end{array}$ \\
\hline \multicolumn{2}{|l|}{ Awareness characteristics } \\
\hline Maximum years of education among adult male members & $\begin{array}{c}12.02 \\
(.11)\end{array}$ \\
\hline Maximum years of education among adult female members & $\begin{array}{c}10.95 \\
(.14)\end{array}$ \\
\hline Percent including "contaminated drinking water" among the causes of diarrhea & $\begin{array}{l}54.15 \\
(1.60)\end{array}$ \\
\hline Percent including "infection" among the causes of diarrhea & $\begin{array}{l}7.72 \\
(.86)\end{array}$ \\
\hline Percent stating "clean water provision" as a government action to prevent diarrhea & $\begin{array}{c}39.69 \\
(1.58)\end{array}$ \\
\hline Percent stating "sanitation provision" as a government action to prevent diarrhea & $\begin{array}{l}35.37 \\
(1.54)\end{array}$ \\
\hline Percent dipping their hands in the storage container when taking water out of it & $\begin{array}{l}29.51 \\
(1.47)\end{array}$ \\
\hline \multicolumn{2}{|l|}{ Demographics \& Diarrhea Cases } \\
\hline Average family size of household & $\begin{array}{c}5.29 \\
(8.31)\end{array}$ \\
\hline Percent of households where head does not work & $\begin{array}{l}24.68 \\
(1.39)\end{array}$ \\
\hline Percent of households with at least one child below 3 years of age & $\begin{array}{l}23.49 \\
(1.36)\end{array}$ \\
\hline Percent of households with at least one diarrhea case in the month prior to survey & $\begin{array}{l}6.70 \\
(.81)\end{array}$ \\
\hline
\end{tabular}

- Standard errors in parentheses

- Estimates are weighted by inverse of sampling probability 
Table 3: Treatment effects on averting behavior, household expenditures, and group discussions (Equation 3)

\begin{tabular}{|c|c|c|c|c|c|c|c|c|c|}
\hline & \multicolumn{3}{|c|}{$\begin{array}{l}\text { Change in water purification, storage } \& \\
\text { handling behavior } \\
\qquad \begin{array}{r}1 \text { if changed behavior } \\
=0 \text { if no change }\end{array}\end{array}$} & \multicolumn{3}{|c|}{$\begin{array}{l}\text { Increase in expenditures related to } \\
\text { water purification } \\
\text { (in Indian Rupees) }\end{array}$} & \multicolumn{3}{|c|}{$\begin{array}{c}\text { Dummy for discussions about water } \\
\text { quality. }\end{array}$} \\
\hline & $\begin{array}{l}\text { Initial non- } \\
\text { purifiers } \\
\quad(\mathrm{N}=569)\end{array}$ & $\begin{array}{l}\text { Initial purifiers } \\
\qquad(\mathrm{N}=396)\end{array}$ & $\begin{array}{c}\text { Full } \\
\text { Sample } \\
(\mathrm{N}=965)\end{array}$ & $\begin{array}{l}\text { Initial non- } \\
\text { purifiers } \\
(\mathrm{N}=569)\end{array}$ & $\begin{array}{l}\text { Initial } \\
\text { purifiers } \\
(\mathrm{N}=396)\end{array}$ & $\begin{array}{c}\text { Full } \\
\text { Sample } \\
(\mathrm{N}=965)\end{array}$ & $\begin{array}{l}\text { Initial non- } \\
\text { purifiers } \\
(\mathrm{N}=569)\end{array}$ & $\begin{array}{l}\text { Initial } \\
\text { purifiers } \\
(\mathrm{N}=396)\end{array}$ & $\begin{array}{c}\text { Full } \\
\text { Sample } \\
(\mathrm{N}=965)\end{array}$ \\
\hline $\begin{array}{l}\text { Treatment } \\
\text { dummy x dirty } \\
\text { source water } \\
\text { result }\end{array}$ & $\begin{array}{l}.108 * * \\
(.043)\end{array}$ & $\begin{array}{l}.116 \\
(.066)\end{array}$ & $\begin{array}{l}.113 * * \\
(.045)\end{array}$ & $\begin{array}{l}65.18 * * * \\
(20.46)\end{array}$ & $\begin{array}{l}-17.25 \\
(51.75)\end{array}$ & $\begin{array}{c}34.22 \\
(24.41)\end{array}$ & $\begin{array}{l}.127 * * * \\
(.040)\end{array}$ & $\begin{array}{c}.134 * * * \\
(.047)\end{array}$ & $\begin{array}{l}.130 * * * \\
(.030)\end{array}$ \\
\hline $\begin{array}{l}\text { Treatment } \\
\text { dummy x clean } \\
\text { source water } \\
\text { result }\end{array}$ & $\begin{array}{l}-.005 \\
(.051)\end{array}$ & $\begin{array}{c}.142 \\
(.083)\end{array}$ & $\begin{array}{l}-.045 \\
(.059)\end{array}$ & $\begin{array}{l}-19.94 \\
(30.47)\end{array}$ & $\begin{array}{c}26.71 \\
(106.06)\end{array}$ & $\begin{array}{c}-2.14 \\
(50.99)\end{array}$ & $\begin{array}{l}.081 * \\
(.047)\end{array}$ & $\begin{array}{c}.123 \\
(.118)\end{array}$ & $\begin{array}{c}.097 \\
(.065)\end{array}$ \\
\hline $\begin{array}{l}\text { Dirty source } \\
\text { water result }\end{array}$ & $\begin{array}{l}.011 \\
(.051)\end{array}$ & $\begin{array}{c}.125 \\
(.072)\end{array}$ & $\begin{array}{c}.022 \\
(.053)\end{array}$ & $\begin{array}{l}-40.30 \\
(27.29)\end{array}$ & $\begin{array}{c}14.76 \\
(56.77)\end{array}$ & $\begin{array}{l}-25.62 \\
(30.66)\end{array}$ & $\begin{array}{l}-.005 \\
(.033)\end{array}$ & $\begin{array}{l}-.048 \\
(.053)\end{array}$ & $\begin{array}{l}-.028 \\
(.032)\end{array}$ \\
\hline Constant & $\begin{array}{c}0.108 * * * \\
(0.041)\end{array}$ & $\begin{array}{c}.338 * * * \\
(.053)\end{array}$ & $\begin{array}{c}.225 * * * \\
(.042)\end{array}$ & $\begin{array}{c}44.39 \\
(27.10)\end{array}$ & $\begin{array}{l}89.18 * \\
(51.53)\end{array}$ & $\begin{array}{c}67.34 * * \\
(29.06)\end{array}$ & $\begin{array}{c}.081 * * * \\
(.029)\end{array}$ & $\begin{array}{c}.128 * * * \\
(.047)\end{array}$ & $\begin{array}{c}.105 * * * \\
(.031)\end{array}$ \\
\hline
\end{tabular}

- Standard errors in parentheses

- Estimates weighted by inverse of sampling probability, corrected for clustering at enumeration block level. The numbers of clusters for initial non-purifiers, initial purifiers, and the full sample are 198, 151, and 205 respectively.

- $\quad * * *$ : significant at $1 \%$ level $\quad * *$ : significant at $5 \%$ level $\quad *$ : significant at $10 \%$

- Purchasing power parity conversion factor: Rs. $9=\$ 1$ 
Table 4: Wealth and awareness as determinants of treatment effects on averting behavior, household expenditures, and group discussions among the 375 initial nonpurifiers with "dirty" water. (Equation 4 in the text).

\begin{tabular}{|c|c|c|c|c|c|c|}
\hline & \multicolumn{2}{|c|}{$\begin{array}{l}\text { Change in behavior } \\
\text { related to purification, } \\
\text { water storage \& } \\
\text { handling }\end{array}$} & \multicolumn{2}{|c|}{$\begin{array}{l}\text { Change in expenditures } \\
\text { related to water } \\
\text { purification } \\
\text { (in Indian Rupees) }\end{array}$} & \multicolumn{2}{|c|}{$\begin{array}{c}\text { Discussions regarding } \\
\text { the survey, water } \\
\text { quality etc. }\end{array}$} \\
\hline & Model 1 & Model 2 & Model 1 & Model 2 & Model 1 & Model 2 \\
\hline & $x_{u}=w_{u}$ & $x_{u}=a_{u}$ & $x_{u}=w_{u}$ & $x_{u}=a_{u}$ & $x_{u}=w_{u}$ & $x_{u}=a_{u}$ \\
\hline Constant & $\begin{array}{c}.121 * * * \\
(.039)\end{array}$ & $\begin{array}{c}.131 * * * \\
(.037)\end{array}$ & $\begin{array}{c}5.21 \\
(5.07)\end{array}$ & $\begin{array}{l}.941 \\
(.923)\end{array}$ & $\begin{array}{c}.085^{* * * *} \\
(.025)\end{array}$ & $\begin{array}{l}.053 * * \\
(.022)\end{array}$ \\
\hline Treatment & $\begin{array}{l}.018 \\
(.053)\end{array}$ & $\begin{array}{l}.096 \\
(.059)\end{array}$ & $\begin{array}{l}25.53 * \\
(14.16)\end{array}$ & $\begin{array}{c}64.44 * * \\
(31.99)\end{array}$ & $\begin{array}{l}.087 * \\
(.045)\end{array}$ & $\begin{array}{l}.093 * * \\
.038)\end{array}$ \\
\hline$x_{u}$ & $\begin{array}{l}-.009 \\
(.057)\end{array}$ & $\begin{array}{l}-.030 \\
(.054)\end{array}$ & $\begin{array}{c}-3.00 \\
(5.34)\end{array}$ & $\begin{array}{c}7.61 \\
(7.96)\end{array}$ & $\begin{array}{l}-.025 \\
(.040)\end{array}$ & $\begin{array}{c}.055 \\
(.042)\end{array}$ \\
\hline Treatment $* x_{u}$ & $\begin{array}{l}.236 * * \\
(.095)\end{array}$ & $\begin{array}{l}-.028 \\
(.088)\end{array}$ & $\begin{array}{c}104.14 * * \\
(51.36)\end{array}$ & $\begin{array}{c}0.71 \\
(41.03)\end{array}$ & $\begin{array}{c}.106 \\
(.080)\end{array}$ & $\begin{array}{c}.068 \\
(.068)\end{array}$ \\
\hline
\end{tabular}

- $w_{u}$ is a dummy for wealth index above the median, $a_{u}$ is a dummy for awareness index above the median.

- Standard errors in parentheses

- Estimates are weighted by inverse of sampling probability, corrected for clustering at enumeration block level (179 clusters).

- $* * *$ : significant at $1 \%$ level

- **: significant at $5 \%$ level

- *: significant at $10 \%$ level 


\section{APPENDIX 1 INDIAN STATISTICAL INSTITUTE}

Dear Madam/Sir,

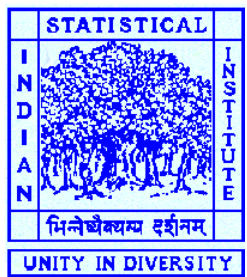

We took drinking water samples to test the water quality in your home during the survey conducted in Nov/Dec 2003. Thank you for your cooperation. We are returning the samples.

The color of the water samples will be yellow or black. If the color is yellow it is most likely that your water does not contain germs. If the color is black, then it is likely that the water is contaminated with germs that may make you sick. But this simple test cannot confirm that the water is contaminated. You may wish to take the following preventive measures:

1. Get your water tested again to confirm whether the water is contaminated or not.

2. Water can get contaminated quite easily within the home, so keep your drinking water storage containers clean and covered at all times. If your water storage container does not have a tap to take out the water, use a clean utensil with a long handle to take out the water. Never dip your hands into the water storage container.

3. Consider using a home water purification method that fits your household's budget. The different methods available and their average prices in Gurgaon are:

\begin{tabular}{|c|c|c|c|}
\hline Method & Equipment Cost & Operating cost & Features \\
\hline $\begin{array}{l}\text { Straining with clean cotton } \\
\text { cloth folded } 8 \text { or more times }\end{array}$ & 0.00 & 0.00 & Limited protection against germs \\
\hline Disinfecting tablets/drops & - & $\begin{array}{l}\$ .10 \text { for } 10 \\
\text { liters of water }\end{array}$ & Kills nearly all germs \\
\hline Non-electric filters & $\$ 25-\$ 345$ & $\$ 9-\$ 35$ per year & $\begin{array}{l}\text { Removes some germs depending on } \\
\text { the fineness of the filter }\end{array}$ \\
\hline Electric filters & $\$ 500-\$ 835$ & $\begin{array}{c}\$ 30-\$ 55 \text { per } \\
\text { year }\end{array}$ & $\begin{array}{l}\text { Kills all germs with UV rays if } \\
\text { properly maintained }\end{array}$ \\
\hline Boiling & - & $\begin{array}{l}\$ 2.45 \text { for } 10 \\
\text { liters of water }\end{array}$ & Kills all germs \\
\hline Drink bottled water & - & $\begin{array}{l}\$ 2.45-\$ 3 \text { for } 10 \\
\text { liters of water }\end{array}$ & $\begin{array}{l}\text { Manufacturer's responsibility to } \\
\text { ensure germ-free water. }\end{array}$ \\
\hline Reverse Osmosis & $\$ 1335-\$ 1665$ & $\$ 85$ per year & $\begin{array}{l}\text { Removes all germs if properly } \\
\text { maintained. }\end{array}$ \\
\hline
\end{tabular}

4. When using purification methods like tablets, non-electric or electric filters, follow the manufacturer's operating and maintenance instructions carefully as well as the water-handling precautions mentioned above. 


\section{$\underline{\text { APPENDIX } 2}$}

\section{Questionnaire used for the third round of our survey}

Date of third round:

Name of surveyors:

1. In our first visit, during the household survey, you had mentioned that you were using purification method/ not using any purification method. Since that visit did you make any changes in the water purification methods you use?

$\square$ Yes $\quad \square$ No

2. If question to (1) is "no" go to question 4. If yes, when and what kind of changes did you make?

Approximate date of change:

$\square$ Adopted new purification method

$\square$ Do not use any purification method any more

$\square$ Others (specify)

3. If answer to question (2) is "adopted new purification method" specify:

Method: Brand name: $\quad$ Fixed cost of the equipment:

Whether any AMC has also been purchased and cost:

4. (Ask only of those households who were previously using either an non-electronic filter or an electronic filter and have not changed their water purification method)

(a) Since our first visit, have you gotten the candles changed (for non-electronic filters) and/or the carbon changed (for electronic filters)? $\square$ Yes $\square$ No

(b) If answer to (a) is "Yes" how much did it cost you?

When did you make the change?

(c) Did you make other expenditures on repairs and/or maintenance of the equipment?

$\square$ Yes $\quad \square$ No.

If "yes" approximate date and amount spent.

5. In our earlier visit you had mentioned that you store your water in

Do you still use the same storage facilities? $\square$ Yes $\quad \square$ No.

(If answer to above is "No" specify the change)

Do you cover your storage container? $\square$ Yes $\square$ No

In our earlier visit you had mentioned that you take the water out from the storage container by using

Do you still use the same method?

(If answer to above is "No" specify the change)

6. Since our first visit, have you discussed the issue of drinking water quality with anyone such as your neighbors, family members, Resident Welfare Associations, doctors, or government organization?

$\square$ Yes $\quad \square$ No

Brief description of your discussion

7. Finally we would like to ask you whether you are planning to make some changes in the future to improve the quality of your drinking water? $\square$ Yes $\square$ No

8. If answer is "yes" to the above question, what kind of changes do you anticipate making?

When do you think you will make this change?

How much do you think you will be able to spend on such changes? 


\section{$\underline{\text { APPENDIX } 3}$}

\section{Calculating costs of different purification methods in Gurgaon}

Straining with a cloth: Zero.

Alum tablet: Each tablet costs a rupee and can be used to purify 10 litres of water, and the households using them reported using one per day.

Ordinary filter: Based on household responses supplemented by a market survey in Gurgaon, we obtained prices of the various brands. The fixed cost was annualized using an assumed life of 10 years and a discount rate of 10 percent.

Boiling: Households reported the time per day that they boiled water, and the fuel used, which was always liquefied petroleum gas. Data from a stove manufacturer was used to calculate gas usage per hour $(177 \mathrm{gm} / \mathrm{hr})$. We used the price of gas in Gurgaon to compute the expenditure for each household.

Electric filter: Based on household responses supplemented by a market survey in Gurgaon, we obtained prices of the various brands. The fixed cost was annualized using an assumed life of 10 years and a discount rate of 10 percent.

Bottled water: We simply used reported household expenditures, checked for consistency using prices and quantities. 


\section{APPENDIX TABLE 1}

Balancing of variables across treatment and control groups

\begin{tabular}{|c|c|c|c|}
\hline Variables & $\begin{array}{l}\text { Treatment } \\
(\mathrm{N}=497)\end{array}$ & $\begin{array}{l}\text { Control } \\
(\mathrm{N}=468)\end{array}$ & $\begin{array}{l}\text { Difference } \\
\text { in means }\end{array}$ \\
\hline $\begin{array}{l}\text { Percentage of households where unpurified water } \\
\text { tested "dirty" }\end{array}$ & 60.69 & 61.23 & $\begin{array}{c}-.54 \\
(3.15)\end{array}$ \\
\hline $\begin{array}{l}\text { Percentage of households where drinking water } \\
\text { tested "dirty" }\end{array}$ & 61.92 & 60.43 & $\begin{array}{l}1.49 \\
(3.14)\end{array}$ \\
\hline $\begin{array}{l}\text { Percentage of households that use a purification } \\
\text { system }\end{array}$ & 40.75 & 42.95 & $\begin{array}{l}-2.20 \\
(3.18)\end{array}$ \\
\hline $\begin{array}{l}\text { Percentage of households that use a purification } \\
\text { system and their water is tested "dirty" }\end{array}$ & 60.03 & 51.88 & $\begin{array}{c}8.15 \\
(4.98)\end{array}$ \\
\hline $\begin{array}{l}\text { Percentage of households that do not use a } \\
\text { purification system and their water is tested "dirty" }\end{array}$ & 63.22 & 66.87 & $\begin{array}{l}-3.65 \\
(4.01)\end{array}$ \\
\hline $\begin{array}{l}\text { Percentage of households with at least one child } \\
\text { below } 3 \text { years of age }\end{array}$ & 23.30 & 23.69 & $\begin{array}{c}-.39 \\
(2.73)\end{array}$ \\
\hline $\begin{array}{l}\text { Percentage of households with at least one episode } \\
\text { of diarrhea in the last month at the time of survey }\end{array}$ & 7.88 & 5.46 & $\begin{array}{c}2.42 \\
(1.61)\end{array}$ \\
\hline
\end{tabular}

\section{APPENDIX TABLE 2}

Balancing of variables across households in the final sample and households that dropped out

\begin{tabular}{lccc}
\hline Variables & $\begin{array}{c}\text { Final } \\
\text { sample } \\
\mathbf{( N = 9 6 5 )}\end{array}$ & $\begin{array}{c}\text { Households that } \\
\text { dropped out of survey } \\
\text { (N=41) }\end{array}$ & $\begin{array}{c}\text { Difference } \\
\text { in means }\end{array}$ \\
\hline $\begin{array}{l}\text { Percentage of treatment households } \\
\begin{array}{l}\text { Percentage of households that used a } \\
\text { purification system }\end{array}\end{array}$ & 51.17 & 59.96 & -8.79 \\
$\begin{array}{l}\text { Percentage of households with at least one } \\
\text { child below 3 years of age }\end{array}$ & 41.82 & 45.67 & -3.85 \\
$\begin{array}{l}\text { Percentage of households with at least one } \\
\text { episode of diarrhea in the last month at the } \\
\text { time of survey }\end{array}$ & 28.07 & 30.65 & -2.58 \\
\hline
\end{tabular}

- Standard errors in parentheses

- Estimates are weighted by inverse of sampling probability 


\section{APPENDIX TABLE 3}

Probability of purification behavior among different wealth categories

\begin{tabular}{|c|c|c|c|}
\hline Explanatory variables & Full Sample & $\begin{array}{l}\text { Upper wealth } \\
\text { category }\end{array}$ & $\begin{array}{l}\text { Lower wealth } \\
\text { category }\end{array}$ \\
\hline Wealth index & $\begin{array}{c}.116^{* * * *} \\
(.01)\end{array}$ & $\begin{array}{c}.184 * * * \\
(.04)\end{array}$ & $\begin{array}{c}.080 * * * \\
(.01)\end{array}$ \\
\hline Awareness index & $\begin{array}{l}.012 \\
(.01)\end{array}$ & $\begin{array}{c}.025^{* *} \\
(.02)\end{array}$ & $\begin{array}{l}-.008 \\
(.01)\end{array}$ \\
\hline Maximum years of education among female adult members & $\begin{array}{l}.008 \\
(.01)\end{array}$ & $\begin{array}{l}.015 \\
.01)\end{array}$ & $\begin{array}{l}.003 \\
(.00)\end{array}$ \\
\hline Maximum years of education among male adult members & $\begin{array}{c}.029 * * * \\
(.01)\end{array}$ & $\begin{array}{c}.047 * * * \\
(.02)\end{array}$ & $\begin{array}{c}.019 * * * \\
(.01)\end{array}$ \\
\hline Proportion of children in the age-group $0-3$ years & $\begin{array}{l}.047 \\
. .04)\end{array}$ & $\begin{array}{l}.013 \\
(.05)\end{array}$ & $\begin{array}{l}.051 \\
.04)\end{array}$ \\
\hline Number of members in household & $\begin{array}{c}-.037 * * * \\
(.01)\end{array}$ & $\begin{array}{c}-.027 * * * \\
(.01)\end{array}$ & $\begin{array}{c}-.040^{* * *} \\
(.01)\end{array}$ \\
\hline Household head is male & $\begin{array}{l}-.013 \\
(.06)\end{array}$ & $\begin{array}{r}-.005 \\
(.08)\end{array}$ & $\begin{array}{l}-.009 \\
(.06)\end{array}$ \\
\hline Age of household head & $\begin{array}{l}.001 \\
. .00)\end{array}$ & $\begin{array}{l}.003 \\
(.01)\end{array}$ & $\begin{array}{l}.002 \\
(.06)\end{array}$ \\
\hline Household head works in public sector & $\begin{array}{l}-.076 \\
(.07)\end{array}$ & $\begin{array}{l}.013 \\
(.11)\end{array}$ & $\begin{array}{c}-.127 * * * \\
(.05)\end{array}$ \\
\hline Household head works in private sector & $\begin{array}{l}.027 \\
.08)\end{array}$ & $\begin{array}{l}.080 \\
(.11)\end{array}$ & $\begin{array}{l}-.069 \\
(.06)\end{array}$ \\
\hline Household head has his/her own business & $\begin{array}{c}-.136 * * * \\
(.06)\end{array}$ & $\begin{array}{l}-.080 \\
.09)\end{array}$ & $\begin{array}{c}-.157 * * * \\
(.05)\end{array}$ \\
\hline Household head works in other services & $\begin{array}{l}-.056 \\
(.06)\end{array}$ & $\begin{array}{l}.007 \\
(.08)\end{array}$ & $\begin{array}{c}-.122 * * * \\
(.04)\end{array}$ \\
\hline Log-likelihood & -529.22 & -298.18 & -219.49 \\
\hline Number of observations & 965 & 483 & 482 \\
\hline
\end{tabular}

Notes:

- Dependent variable:

$y=1$ if household adopts some purification method

$=0$ otherwise

- Standard errors are reported in parentheses

- Estimates are weighted by inverse of sampling probability, corrected for clustering at enumeration block level

- Upper and lower wealth categories are defined if the household's wealth index is above or below median wealth index.

- *** indicates significance at 5 percent or lower

- ** indicates significance levels between $5-10$ percent 


\section{Figure 1: Time-line of survey process}

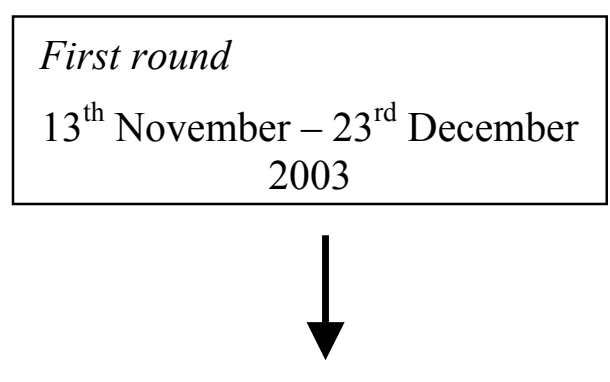

Second round (Treatment)

$17^{\text {th }}$ January $-1^{\text {st }}$ February 2004

Third round (Control)

$1^{\text {st }}$ March $-12^{\text {th }}$ March 2004

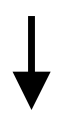

Third round (Treatment)

$13^{\text {th }}$ March $-28^{\text {th }}$ March 2004
All 1,006 households surveyed and water samples taken
$\Longrightarrow$ Randomly selected 520 households given water test results and handout
Households not covered in second round, resurveyed for changes in purification behavior, and then given test results and handout
Households covered in second round revisited and resurveyed for changes in purification behavior 
Figure 2
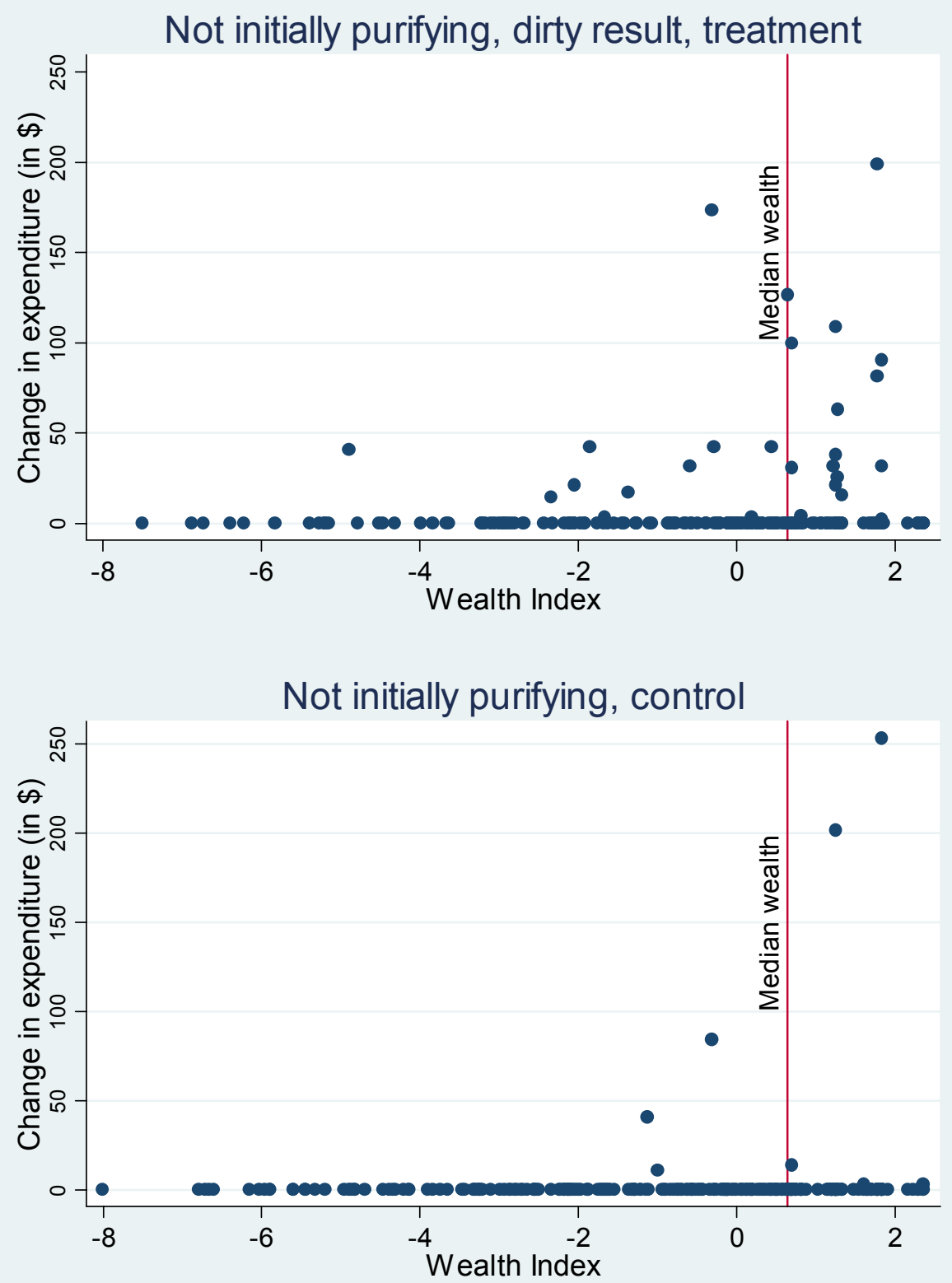